Review Article

\title{
Edible flowers: traditional and current use
}

\author{
Izabel Cristina dos Santos ${ }^{1 *}$ ([) , Simone Novaes Reis ${ }^{1}$ (i) \\ ${ }^{1}$ Empresa de Pesquisa Agropecuária de Minas Gerais (EPAMIG), Campo Experimental Risoleta Neves, São João del Rei-MG, Brazil.
}

\begin{abstract}
Flowers have been part of human life since antiquity. Several civilizations have left the legacy of using flowers in art, natural medicine, as well as in cooking to color, flavor and embellish various dishes. Edible flowers (EF) are those that can be consumed without endangering consumer's health. Although not all countries in the world use flowers for food, their use has increased in general, as well as the interest of researchers from different areas of knowledge, as they are considered new sources of nutrients and bioactive compounds. However, the safety of its use is still questioned due to the lack of more information about the maximum safe amount of daily intake. This review aimed to gather information about the traditional use of EF, safety in consumption and consumers' perception of these products.
\end{abstract}

Keywords: floriculture, flowers for food, food safety.

\section{Resumo}

Flores comestíveis: usos tradicional e atual

Flores fazem parte da vida humana desde a antiguidade. Várias civilizações deixaram como legado o uso de flores na arte, medicina natural, bem como na culinária para colorir, aromatizar, saborizar e embelezar pratos diversos. As flores comestíveis (FC) são aquelas que podem ser consumidas sem colocar em risco a saúde do consumidor. Embora nem todos os países do mundo utilizem flores na alimentação, seu uso tem aumentado de uma maneira geral, bem como o interesse de pesquisadores de diversas áreas do conhecimento, pois são consideradas novas fontes de nutrientes e compostos bioativos. Mas ainda se questiona a segurança do seu uso por causa da falta de mais informações sobre quantidade máxima segura de ingestão diária. A revisão aqui apresentada teve por objetivo levantar informações sobre o uso tradicional das FC, a segurança no consumo e a percepção dos consumidores sobre esses produtos.

Palavras-chave: floricultura, flor na alimentação, segurança alimentar.

\section{Introduction}

The sight of a flowering field or the thrill of receiving a beautiful bouquet of flowers are always pleasant sensations. This pleasure can also be felt in meals when you eat edible flowers (EF) in salads or dishes decorated with them, or when you smell their aroma in beverage or food in which they were used as an ingredient.

Although the use of flowers in natural medicine and in food is an ancient habit, it has been observed in some countries that, in the last decades, their use in cooking has been more valued due to the change in people's habits, who have been looking for natural food or functional properties that increase health and prevent diseases. Such behavior has led to an increase in the consumption of EF and research in several areas of science that answer the questions: Why eat flowers? Is it safe to eat them? What do consumers think about edible flowers?
In this review, information based on scientific research was sought to answer these questions, collaborating to enable a safe consumption of flowers as food.

\section{Tradition in the use of edible flowers}

The current habit of eating flowers is a legacy of cultures that have used them for centuries (Demasi et al., 2021). EF have been used in Asian, European, Indian and Middle Eastern cuisine, in connection with local traditions, festive occasions and banquets, as well as in natural medicine (Mlcek and Rop, 2011; Rop et al., 2012; Guarrera and Savo, 2013; Lauderdale and Bradley, 2014; Zheng et al., 2018; Drava et al., 2020; Guiné et al., 2020; Demasi et al., 2021; Kumari et al., 2021).

In ancient civilizations, EF were used as flavoring agents in food preparation and in the decoration of dishes. In ancient Rome, Rosa spp. petals were used to sweeten

*Corresponding author: icsantos@epamig.br

https://doi.org/10.1590/2447-536X.v27i4.2392

Received: May 04, 2021 | Accepted: June 1st, 2021 | Available online: July 12, 2021

Licensed by CC BY 4.0 (https://creativecommons.org/licenses/by/4.0/)

Area Editor: Márkilla Zunete Beckmann-Cavalcante and Patrícia Duarte de Oliveira Paiva 
and taste omelets, purees, beverages and desserts. In the Middle Ages, the flower petals of Calendula officinalis were used in France in various types of salads; in the 17th century, Viola odorata was used to color sugar, syrups and other beverages (Mlcek and Rop, 2011; Takahashi et al., 2020). In Central Europe, it is common to consume breaded Sambucus nigra flowers and Taraxacum officinale flowers boiled with sugar to replace honey (Mlcek and Rop, 2011; Rop et al., 2012).

Some species consecrated as vegetables are actually flowers or parts of it: from artichoke (Cynara scolymus), we eat the inflorescence bracts; from cauliflower (Brassica oleracea var. botrytis), the inflorescence itself; from broccoli (Brassica oleracea var. italica), the flower stems with closed buds (Santos et al., 2019b).

At the turn of the 20th century and the beginning of the 21 st century, there was a movement to value wild plants, especially native plants, which began to be extolled by the media and to be part of the culinary ingredients in TV programs, magazines, websites and cookbooks. Among them are EF, used both as a decorative element and as an ingredient in recipes, greatly contributing to the dissemination of their use among the general population. Still, EF are not widely known in all countries (Mlcek and Rop, 2011; Rodrigues et al., 2017; Egebjerg et al., 2018; Matyjaszczyk and Smiechowska, 2019; Rivas-García et al., 2020; Guiné et al., 2020).

In the United States of America, Creasy (1999) published the book "Edible Flower Garden", which brings, for various species that produce EF, information on planting, maintenance, pests and diseases, as well as recipes. In the book "Botanicals with Benefits: Develop a new relationship with your garden: the Edible Flower volume" (Hughes, 2020) describes ways of preparing and characteristics of several EF species. Other titles, printed or in an online version are available, with information for the general public to know, cultivate in gardens and use EF. Kaiser and Ernst (2021) cite several publications from American universities with information on $\mathrm{EF}$ in a language accessible to the general public. Kaisoon et al. (2012) report that the native population of Northern Thailand frequently uses the flowers of Tagetes erecta, Cosmos sulphureus, Antigonon leptopus and Bougainvillea glabra, in the preparation of salads and flower teas.

The term 'floriphagia' was used by Lara-Cortés et al. (2013) to define the consumption of fresh, freshly picked flowers, with nutritional or functional characteristics, or with some therapeutic and sensory action related to their appearance or taste. The authors point out that exotic Mexican cuisine has been using EF for many generations.

The importance of flowers with their multiple uses led Deka and Nath (2014) to carry out a study on documenting the species and the traditional knowledge associated with them in the West Assan region, in India. During two years, 35 species from 23 families were identified, with information on flowering season, uses, medicinal properties and commercialization. It is very common in the region to use raw EF, right after harvest, but also in cooked dishes. Some flowers are dried and stored for consumption outside the flowering season. Still in relation to India, Kumari et al. (2021) claim that edible wildflowers play a vital role in the food and nutritional security of traditional rural populations, as part of the aspects of their socio-cultural and spiritual life. Furthermore, there is a great diversity of palatable flowers and forms of use among the different socio-geographic regions. In Mexico, Mulík and Ozuna (2020) described cultural habits, uses in traditional cuisine and potential benefits of the most used EF. In this country, the flowers were registered with varied symbologies in pyramids, sculptures, caves and ceramic painting. Colonization by the Spanish mixed cultures and flowers began to replace meat in the diet due to the customs of the Catholic Church during Easter celebrations. EF are used raw, in the preparation of hot dishes, desserts and for flavoring beverages. Among the most appreciated and cultivated species in Mexico are Cucurbita sp., Erytrhrina americana, Yucca spp., Tagetes erecta, Dahlia spp., Plumeria rubra, Opuntia ficus-indica, Ferocactus sp., Myrtillocactus geometrizans, Agave spp., Euphorbia pulcherrima and Phaseolus coccineus. The production of flowers already existed before the arrival of the Spaniards, and there was prejudice regarding their consumption, which was related to poverty and is still not favored in the region (Del Angel-Perez and Mendonza, 2004; Manzanero-Medina et al., 2020; cited by Mulík and Ozuna, 2020).

In Brazil, some flowers were already used in food due to habits introduced by European and Asian immigrants (pumpkin flower, artichoke, broccoli, cauliflower, banana bract inflorescence and medicinal plant flowers (Felippe, 2003; Santos et al., 2019a; Santos et al., 2019b). The popularization of 'unconventional food plants' helped put EF in evidence. Kinupp and Lorenzi (2014) present a botanical description, most common uses and recipes for many EF.

If, on the one hand, the use of EF is very dependent on the culinary tradition of each people, on the other hand it is dependent on the innovations and trends of contemporary gastronomy. When chefs value these ingredients, using them in traditional or in new recipes, they contribute to their popularization (Matyjaszczyk and Smiechowska, 2019; Guiné et al., 2019; Rodrigues et al., 2017), as they know how to use their attractive colors, exquisite aromas and exotic flavors to enhance their dishes.

With their great visual and aromatic appeal, EF have conquered space in the food and ingredients market for gourmet gastronomy. Fresh flowers decorate beverages or color and flavor jellies, wines and vinegars; fresh or cooked, they can be used in cold or hot dishes, with meat and fish; dehydrated, they can flavor salt, sugar or be used for infusions; candied, they can decorate sweet dishes and desserts; they can also be used dried and ground (Chen and Wei, 2017; Guiné et al., 2019; Guiné et al., 2020; Takahashi et al., 2020; Drava et al., 2020).

EF have a wide variety of colors, textures, sizes and flavors and in Figure 1 are examples of some that are consumed in various parts of the world. 


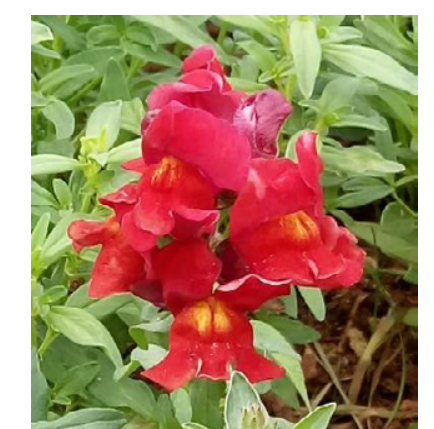

Antirrhinum majus, Snapdragon

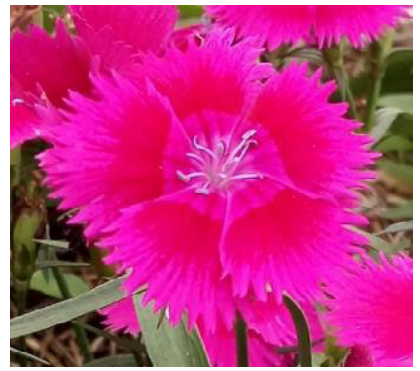

Dianthus chinensis, Chinese pink

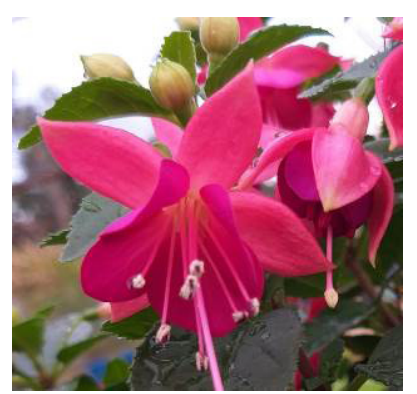

Fuchsia hybrida, Fucsia

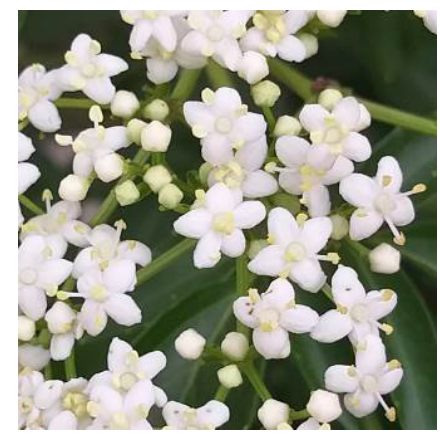

Sambucus nigra, Elderflowers

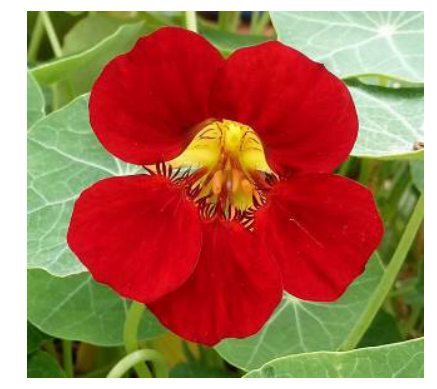

Tropaeolum majus, Nasturtium

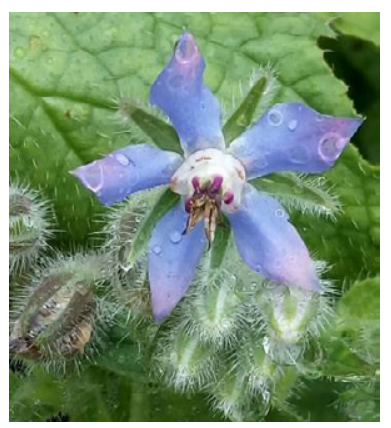

Borago officinalis, Borage

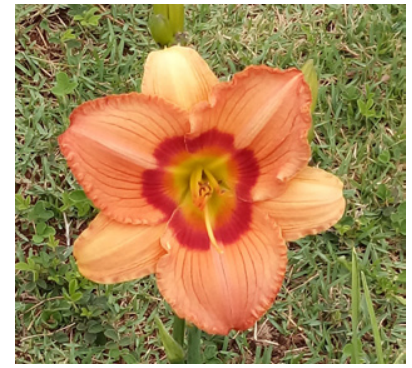

Hemerocallis spp., Day lily

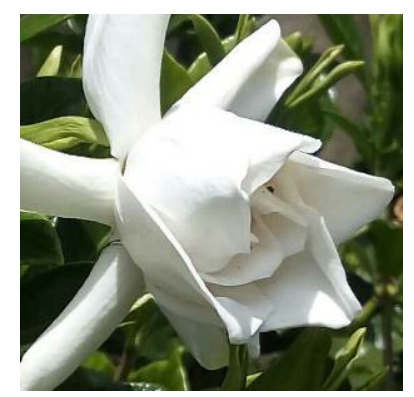

Gardenia jasminoides, Gardenia

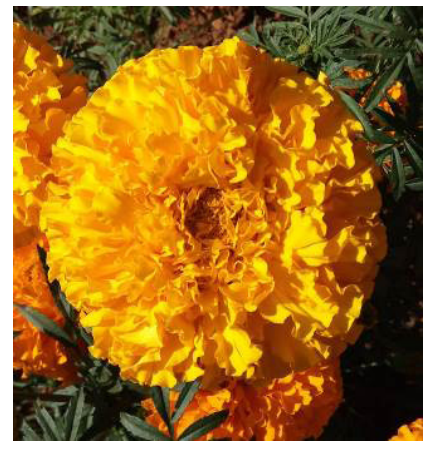

Tagetes spp., Marigold

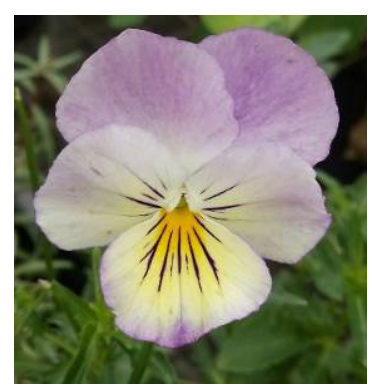

Viola tricolor, Johnny Jump Ups

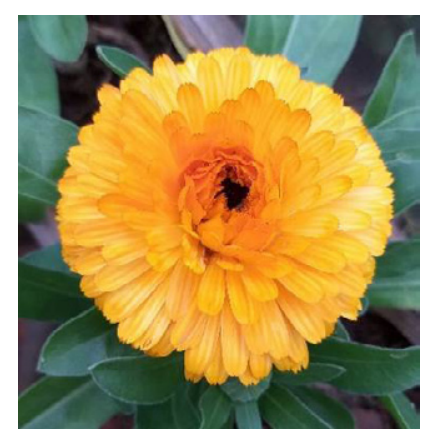

Calendula officinalis, Pot marigold

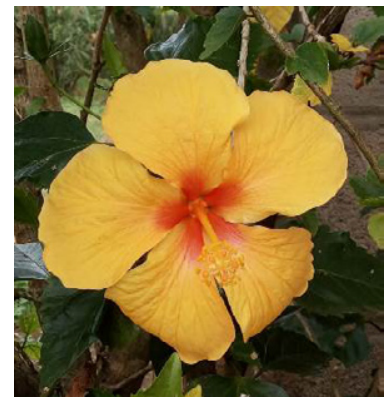

Hibiscus rosa-sinensis, Chinese hibiscus

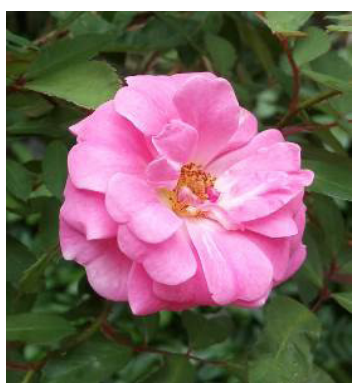

Rosa spp., Rose

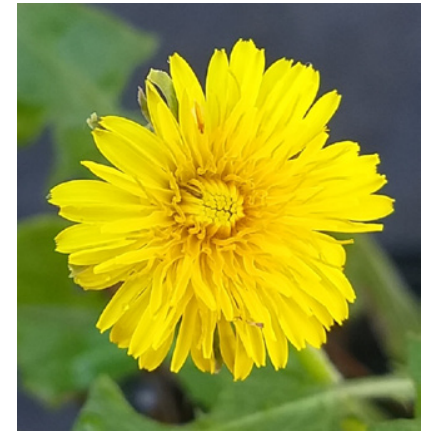

Taraxacum officinale, Dandelion

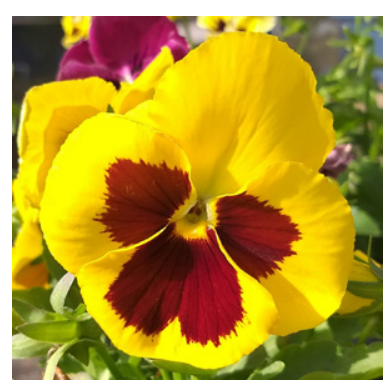

Viola $\times$ wittrockiana, Pansy

Figure 1. Examples of plant species with edible flowers. 
Due to this increase in interest in EF, research on the species produced and consumed, their nutritional value and health benefits has been carried out in several countries (Mlcek and Rop, 2011; Kaisoon et al., 2012; Lara-Cortés et al., 2013; Chen and Wei, 2017; Egebjerg et al., 2018; Zheng et al., 2018; Drava et al., 2020; Fernandes et al., 2020; Mulík and Ozuna, 2020; Takahashi et al., 2020; Demasi et al., 2021; Kumari et al., 2021). Other studies focused on consumer preferences and behavior (Chen and Wei, 2017; Rodrigues et al., 2017; Guiné et al., 2017; Guiné et al., 2020; Guiné et al., 2021), in order to better explore the different characteristics of EF to create new products and expand markets in the coming decades (Takanachi et al., 2020; Kumari et al., 2021).

\section{Consumer behavior towards edible flowers}

The use of EF in food has always been linked to festive occasions, habits and traditions in each country (Lauderdale and Bradley, 2014; Drava et al., 2020; Mulík and Ozuna, 2020). However, over time and as a function of globalization, they have lost space in cooking to other ingredients that are easier to use. In the last decades, its various possibilities of use and nutritional appeal have aroused the interest of new consumers, being more valued, which is due, in part, to more sophisticated chefs in restaurants and buffets. Even so, they are not well known in all countries (Nicolau and Gostin, 2016; Chen and Wei, 2017; Rodrigues et al., 2017; Pires et al., 2017; Guiné et al., 2020; Guiné et al., 2021).

The use of EF is popular in European countries such as England, Spain, France (Yamamoto and Kano, 2018), Italy (Ombra et al., 2019), and in Asian countries such as India and Taiwan (Deka and Nath, 2014; Chen and Wei, 2017; Kumari et al., 2021). In America, Mexico has a tradition of using EF (Mulík and Ozuna, 2020) and, according to Lauderdale and Bradley (2014), the first American colonizers used EF in food. In the Nordic countries, Egebjerg et al. (2018) report that, after the beginning of the 21 st century, it was possible to observe the emergence of the 'new Nordic cuisine', a movement that values locally produced foods, including wild plants and, among them, edible flowers.

The inclusion of EF in food is part of a choice of the individual, as with any other food; it may be related to quality, but also to economic, social and cultural factors (Guiné et al., 2020). While for some people who consume EF what matters is the harmonious combination of color, flavor, aroma and shape that the flowers provide to the dish, making it more attractive, for others who seek a healthier diet, the most important is the nutritional value and the fact that they are fresh, minimally processed foods. There are still those who try EF just out of curiosity (Rop et al., 2012; Chen and Wei, 2017).

Due to the increasing interest in EF, research on consumer perception and behavior has been carried out in some countries. In Taiwan, Chen and Wei (2017) conducted a study on the behavior of 357 consumers regarding their attitude towards consumption of what they called 'flower foods', that is, edible flowers in fresh or dried form, in salads or desserts. Flower teas and food supplements containing flowers were not considered. They concluded that curiosity is the factor that most influences the attitude towards the consumption of EF, followed by the aroma. However, among respondents who had more experience with $\mathrm{EF}$, a healthy lifestyle and health care also influence the attitude of consuming them.

To learn about the behavior of the Portuguese regarding the use of flowers in food, Guiné el al. (2017) interviewed 100 people and concluded that $91 \%$ of them had already heard about EF; $76.81 \%$ had already eaten at least once and, among them, the most consumed flowers were chamomile $(60.5 \%)$ and sunflower $(47.4 \%)$, followed by pumpkin flower, pansy, orchid and others outnumbered. Regarding the frequency of consumption, $43.4 \%$ responded sporadically, while $56.6 \%$ replied that they regularly consumed EF. For $73.7 \%$ of people, nutritional value is the biggest reason for consumption, followed by taste $(68.4 \%)$, antioxidant activity $(27.6 \%)$, aroma $(25 \%)$, decorative value $(25 \%)$ and, finally, the novelty factor $(6.3 \%)$. Those who consume EF acquire them in supermarkets $(93.8 \%)$ or have their own cultivation (45.3\%). Among Portuguese respondents, the most common form of consumption is cooked dishes $(98.4 \%)$, followed by fresh $(43.8 \%)$, and $51 \%$ are in favor of a regular consumption of EF. Most of the interviewees believe that there is not sufficient information about EF and that this can be an impediment to spread its use, but that the use in gastronomy is very attractive and can contribute to this. The authors also concluded that there is a niche market for EF but, for this market to consolidate, some doubts need to be clarified among consumers, such as the risks inherent in the consumption of EF and which are exactly the flowers that can be used in food. They suggested that cookbooks including EF as ingredients would help in the popularization of their use.

In Brazil, Rodrigues et al. (2017) investigated the behavior of 549 consumers in relation to two food groups: a) food made with flowers and b) yogurt made with flowers. The attitude of consumers was positive in both cases; they associated the product made with flowers to 'health care' and the yogurt made with flowers to 'innovative product'.

Continuing the study on consumer behavior in relation to EF, Guiné et al. (2020) interviewed 290 people in Portugal and Costa Rica. More people heard about EF in the European country than in the Latin American country (96.7\% and $76.3 \%$, respectively) and $96 \%$ of all respondents said that the availability of information about EF is not sufficient. Regarding the risks associated with the consumption of EF, $83.8 \%$ believed there was a risk of toxicity (of the flower) and $80.9 \%$ believed there was a possibility of contamination by pesticides. In Portugal and Costa Rica, restaurant was the most cited place when people were asked where they ate EF for the first time (46\%), followed by their own home (30\%), cafes and pastry shops (4\%). Eighty-five percent of respondents considered the use of EF in gastronomy interesting, but a small percentage felt that EF should be consumed more frequently. In Costa 
Rica, $47.7 \%$ of people had already tried EF and they all said that they eat EF sporadically. In Portugal, $47.5 \%$ of respondents had already tried EF; among them, $88 \%$ said they eat flowers sporadically and $12 \%$ that they regularly consume EF. In both countries, the most common forms of EF consumption are in the decoration or preparation of dishes $(77 \%)$ and in salads $(75 \%)$. Other forms mentioned were: starters, jellies and flavor enhancers). Among the respondents, the most consumed flowers were chamomile and rose (62\% of respondents); the first most frequently in Costa Rica and the second in Portugal. The pumpkin flower had been consumed by $49 \%$ of people; pansy, $38 \%$; sunflower, $32 \%$; marigold, $26 \%$, orchid, $10 \%$. For respondents from both countries, the most relevant reasons for using $\mathrm{EF}$ in food were the ability to embellish any culinary preparation $(66 \%)$, the exquisite taste $(62 \%)$, the feeling of experiencing something new (62\%), aroma and bouquet $(57 \%)$, the presence of bioactive compounds that have antioxidant activity (37\%), the nutritional value, especially micronutrients and vitamins (26\%), among others $(21 \%)$. However, while the Portuguese value the decorative aspect (74\%) and the novelty (69\%) more, Costa Ricans value flavor $(70 \%)$ and then the decorative aspect (58\%).

To compare the use of EF in gastronomy, as well as the factors that determine this practice, Guiné et al. (2021) chose three countries (Brazil, Portugal and Slovenia), representing three different geographical regions of the globe and the questionnaire was answered by 559 people. Regardless of the country, consumers were familiar with the use of EF in gastronomy and, in general, had already consumed it. The consumer's country of origin and their education background were the most important factors in determining the knowledge and habits of EF consumption. The use is more popular in Portugal and less in Brazil; the reasons for the consumption of EF, the type of EF consumed and the form of use were significantly different between countries. Such results show that eating habits are very dependent on the traditions and customs of each country and help understand consumers' attitudes towards EF.

\section{Safety in the use of flowers as food}

EF are receiving renewed attention around the world and their market is expanding, mainly due to the increase in their use in gastronomy ((Rop et al., 2012; Guiné et al., 2017; Egebjerg et al., 2018; Guiné et al., 2021; Kaiser and Ernst, 2021) and the interest of various industries in new ingredients for the development of new products (Franzen et al., 2018; Takahashi et al., 2020; Rivas-García et al., 2020).

The use of flowers as food is not new and is based on the fact that they have been used for thousands of years around the world, in natural medicine and in food (Rop et al., 2012; Kaisoon et al., 2012; Deka and Nath, 2014; Mulík and Ozuna, 2020). It was the ancient civilizations that, when trying flowers as food, identified those "edible" and "non-edible" and many species were, then, consecrated by the tradition passed from generation to generation. It is currently known that it is the amount of alkaloids (chemical substances responsible for the defense system of plants) that separate these two plant categories (Nicolau and Gostin, 2016). According to these authors, inedible flowers contain alkaloids that have a psychotropic effect and stimulating activity, or toxic alkaloids, which make the flowers poisonous. Alkaloids are not evenly distributed in the plant or flower and most of them are bitter. Thus, knowing where the alkaloids accumulate allows to decide whether or not to use a flower in the diet, or which part of a flower can be ingested without the risk of intoxication. As the consumer does not have this type of information, educational and research institutions around the world develop brochures, booklets and illustrated guides to help people safely recognize and choose which flowers or which part of the flowers to use as food (University of Kentucky, 2012; Lauderdale and Bradley, 2014; Nicolau and Gostin, 2016; Santos et al., 2019b; Kinupp and Lorenzi, 2014; Kaiser and Ernest, 2021).

However, questioning about safety in consumption is frequent, both among researchers and among consumers (Cunningham, 2015; Nicolau and Gostin, 2016; Egebjerg et al., 2018; Matyjaszczyka and Śmiechowskab, 2019; Kumari et al., 2021). Flowers are very attractive and can appear palatable and harmless, but they may contain toxic principles that cause serious problems to human health; therefore, the possibility of intoxication by eating flowers is a focus of interest and discussion (Lara-Cortés et al., 2013; Nicolau and Gostin, 2016; Guiné et al., 2017; Fernandes et al., 2017; Egebjerg et al., 2018; Franzen et al., 2018; Matyjaszczyka and Śmiechowskab, 2019; Guiné et al., 2020; Kumari et al., 2021; Guiné et al., 2021).

To avoid this type of problem, it is necessary to be sure of the correct identification of the plant species that will be used for the production of EF (Mlcek and Rop, 2011; Nicolau and Gostin, 2016; Egebjerg et al., 2018; Santos et al., 2019a; Guiné et al., 2021). Popular names can cause great confusion. For example, due to the white color of its cup-shaped inflorescence, the plant Zantedeschia aethiopica is known in Brazil as 'calla lily', which refers to the image of a food, but this inflorescence is toxic. Another example: among the plants known as lilies, flower buds and petals of Hemerocallis x hybrida can be ingested in small amounts, while other lilies are toxic, such as Amaryllis belladonna and Gloriosa rothschildiana (Nicolau and Gostin, 2016).

The term 'edible flower' is being used worldwide, but it can lead people to believe that all parts of the flower are edible; in fact, only petals are used in most EF, or ligules in the case of flowers from the Asteraceae family. Even so, it is necessary to pay attention once, in some petals, such as Dianthus chinensis, Rosa spp. and Calendula officinalis, the base must be discarded as it has a bitter taste (Nicolau and Gostin, 2016; Fernandes et al., 2017; Santos et al., 2019b). Sepals should be removed from all flowers, except for Viola odorata, Viola tricolor, Viola $\mathrm{x}$ wittrockiana and Tropaeolum majus (Kaiser and Ernst, 2021; Santos et al., 2019b).

For some EF in more common use, it is known that it is safer to ingest small amounts, as in the case of Tilia cordata and Hemerocalis, but this information is not available for all EF. Therefore, it is recommended to ingest small amounts and observe the reaction of each individual; people with 
asthma, allergy or hay fever should avoid consuming EF, especially those who are allergic to pollen (Lauderdale and Bradley, 2014; Cunningham, 2015; Nicolau and Gostin, 2016; Guiné et al., 2017).

According to Wetzel et al. (2010), little has been studied about the possibilities of edible flowers as a source of contaminants that cause foodborne diseases, since these products are consumed raw, and sometimes without proper asepsis, to preserve aesthetic characteristics. By analyzing samples of basil and some edible flowers, these researchers identified at least 8 potential microorganisms that cause poisoning. Matyjaszczyka and Śmiechowskab (2019) also warn of the danger of external contamination of EF with bacteria and chemical compounds, remembering that microorganisms may come from the production field due to, for example, poor quality irrigation water, or contamination of the product during handling, cleaning and packaging. Chemical contamination, on the other hand, can originate from air pollution or the use of pesticides in areas close to the cultivation of EF (Mlcek and Rop, 2011; Lauderdale and Bradley, 2014; Santos et al., 2019b; Matyjaszczyka and Śmiechowskab, 2019). In addition to external contamination, the reproductive organs of flowers contain alkaloids and pollen, and must therefore be removed before use; after that, the EF must be sanitized to remove dust and small insects, immersing them in water, rinsing and drying on paper towels (Lauderdale and Bradley, 2014; Nicolau and Gostin, 2016; Kaiser and Ernst, 2021).

Lara-Cortés et al. (2013) report about the lack of regulation for the use of flowers as food, which is corroborated by Matyjaszczyka and Śmiechowskab (2019), who observed a lack of safety requirements and guidelines for the production and consumption of EF. No international body, such as FAO (Food and Agriculture Organization of the United Nations), FDA (Food and Drug Administration - USA) or EFSA (European Food Safety Authority) has released an official list of edible flowers or made recommendations on maximum amounts for the daily intake of each species (Demasi et al., 2021). Therefore, the most prudent approach is to gradually introduce them into the diet, ingesting small amounts at a time (Lauderdale and Bradley, 2014).

To increase the safety in the use of EF, they cannot be purchased in nurseries or florists, as plants can receive chemical products in these places to defend them from pests and diseases. Cut flowers receive pesticides in the field and preservatives that help them increase their pot life and in flower arrangements. Nor should flowers be harvested by the side of the road or in gardens open to the circulation of domestic animals, as they may be contaminated with dust and animal faeces and urine residues (Lauderdale and Bradley, 2014; Nicolau and Gostin, 2016; Santos et al., $2019 b)$. Therefore, the correct is to purchase edible flowers that have been produced in an organic system, to ensure that they do not have residues of pesticides, biological contaminants and polluting particles.

In Europe, the collection of wild plants is encouraged. If EF are collected from nature, this must be done by a very experienced person, or based on reliable guides and illustrated books; the consumer should seek to know the origin of the flower (if it was collected, if it was cultivated) and trust the seller (Nicolau and Gostin, 2016; Egebjerg et al., 2018). In Denmark, famous restaurants are using wild plants as ingredients for their dishes, including 23 edible flowers. Egebjerg et al. (2018) made a safety assessment in the use of these EF, based on scientific publications on phytochemical evaluation and toxicological data in humans and animals (domestic, breeding, experimentation). Among the $23 \mathrm{EF}$, nine contained compounds with toxic or potentially toxic effect if ingested, two contained unidentified toxic compounds and four were plant flowers with potentially toxic compounds in other parts of the plant or in plants of botanically related species. They also considered that many of the EF used in Denmark can be considered "new", as historical data on their use as food are limited.

\section{Conclusions}

Edible flowers can contribute to increase the attractiveness of different types of culinary preparations. Although the use of flowers in food seems a novelty, it is a legacy of ancient civilizations. For this reason, many EF have their use consecrated by tradition but, for many species, it is still necessary to deepen the knowledge about the chemical composition and, mainly, regarding the maximum daily amount to be ingested. It is also necessary that the knowledge reaches the producers and consumers, in order to increase confidence and security in the use of these products.

\section{Acknowledgements}

The authors would like to thank FAPEMIG, for the financial support.

\section{Author Contribution}

ICS: idea, bibliographic review and article writing. SNR: bibliographic review and article writing.

\section{References}

CHEN, N.H.; WEI, S. Factors influencing consumers' attitudes towards the consumption of edible flowers. Food Quality and Preference, v.56, part A, p.93-100, 2017. https://doi.org/10.1016/j.foodqual.2016.10.001

CREASY, R. Edible Flower Garden. North Clarendon: Tutle Publishing, 1999. 106p.

CUNNINGHAM, E. What nutritional contribution of edible flowers make? Journal of the Academy of Nutrition and Dietetics, v.115, n.5, 856, 2015. https://doi.org/10.1016/j. jand.2015.03.002

DEKA, K.; NATH, N. Documentation of edible flowers of Western Assam. American Journal of Phytomedicine and Clinical Therapeutics, v.2, n.10, p.1124-1140, 2014. 
DEMASI, S.; CASER, M.; DONNO, D.; ENRI, S.R.; LONATI, M.; SCARIOT, V. Exploring wild edible flowers as a source of bioactive compounds: New perspectives in horticulture. Folia Horticulturae, v.33, n.1, p.1-22, 2021. https://doi.org/10.2478/fhort-2021-0004

DRAVA, G.; IOBBI, V.; GOVAERTS, R.; MINGANTI, V.; COPETTA, A.; RUFFONI, B.; BISIO, A. Trace elements in edible flowers from Italy: further insights into health benefits and risks to consumers. Molecules, v.25, 2891, 2020. https://doi.org/10.3390/molecules25122891

EGEBJERG, M.M.; OLESEN, P.T.; ERIKSEN, F.D; RAVN-HAREN, G.; BREDSDORFF, L.; PILEGAARD, $\mathrm{K}$. Are wild and cultivated flowers served in restaurants or sold by local producers in Denmark safe for the consumer? (Review). Food and Chemical Toxicology, v.120, p.129142,2018

FELIPPE, G.M. Entre o jardim e a horta: as flores que vão para a mesa. 2ed. São Paulo: Editora Senac, 2003. 286p.

FERNANDES, L.; CASAL, S.; PEREIRA, J.A.; SARAIVA, J.A; RAMALHOSA, E. Edible flowers: A review of the nutritional, antioxidant, antimicrobial properties and effects on human health. Journal of Food Composition and Analysis, v.60, p.38-50, 2017. https:// doi. org/10.1016/j.jfca.2017.03.017

FERNANDES, L.; RAMALHOSA, E.; PEREIRA, J.A.; SARAIVA, J.A.; CASAL, S. Borage, camellia, centaurea and pansies: nutritional, fatty acids, free sugars, vitamin E, carotenoids and organic acids characterization. Food Research International, v.132, Article 109070, 2020. https://doi.org/10.1016/j.foodres.2020.109070

FRANZEN, F.L.; LIDÓRIO, H.F.; OLIVEIRA, M.S.R. Edible flower considerations as ingredients in food, medicine and cosmetics. Journal of Analytical \& Pharmaceutical Research, v.7, n.3, p. 271-273, 2018. 10.15406/japlr.2018.07.00238

GUINÉ, R.P.F.; FLORENÇA, S.G.; FERRÃO, A.C.; BIZJAK, M.C.; VOMBERGAR, B.; SIMONI, N.; VIEIRA, $\mathrm{V}$. Factors affecting eating habits and knowledge of edible flowers in different countries. Open Agriculture, v.6, p.6781, 2021. https://doi.org/10.1515/opag-2020-0208

GUINÉ, R.P.F.; FLORENÇA, S.G.; VILLALOBOS MOYA, K.V.; ANJOS, OFÉLIA. Edible flowers, old tradition or new gastronomic trend: a first look at consumption in Portugal versus Costa Rica. Foods, v.9, n.8, p.977, 2020. https://doi.org/10.3390/foods9080977

GUINÉ, R.P.F., FLORENÇA, S.G., FERRÃO, A.C., CORREIA, P.M.R. Investigation about the consumption of edible flowers in Portugal. Indian Journal of Traditional Knowledge, v.18, n.3, p. 579-588, 2017.
GUARRERA, P.; SAVO, V. Perceived health properties of wild and cultivated food plants in local and popular traditions of Italy: a review. Journal of Ethnopharmacology, v.146, p.659-680, 2013. https://doi.org/10.1016/j.jep.2013.01.036

HUGHES, K. Botanicals With Benefits: develop a new relationship with your garden: The Edible Flower Volume. Vallejo: EthnoPharm, 2020. 38p.

KAISER, C.; ERNEST, M. Edible Flowers. Lexington, KY: Center for Crop Diversification, University of Kentucky, College of Agriculture, Food and Environment. April/2021. 4p. Available at: http://www.uky.edu/ccd/sites/www.uky. edu.ccd/files/edible.pdf. Accessed on: may 13 2021 .

KAISOON, O.; KONCZAK, I.; SIRIAMORNPUN, S. Potential health enhancing properties of edible flowers from Thailand. Food Research International, v.46, p.563571, 2012. 10.1016/j.foodres.2011.06.016

KINUPP, V.F.; LORENZI, H. Plantas alimentícias não convencionais (PANC) no Brasil: guia de identificação, aspectos nutricionais e receitas ilustradas. Nova Odessa: Instituto Plantarum de Estudos da Flora, 2014. 768p.

KUMARI, P.; UJALA, N; BHARGAVA, B. Phytochemicals from edible flowers: opening a new arena for healthy lifestyle. Journal of Functional Foods, v.78, p.104375, 2021. https://doi.org/10.1016/j.jff.2021.104375.

LARA-CORTÉS, E.; OSORIO-DÍAZ, P.; JIMÉNEZAPARICIO, A.; BAUTISTA-BAÑIOS, S. Contenido nutricional, propiedades funcionales $\mathrm{y}$ conservación de flores comestibles. Revisión [Nutritional content, functional properties and conservation of edible flowers. Review]. Archivos Latinoamericanos de Nutrición, v.63, n.3, p. 197-208, 2013.

LAUDERDALE, C.; BRADLEY, L. Choosing and using edible flowers. Raleigh, North Caroline, USA: Department of Horticultural Science North Carolina State University, NC State Extension; 2014. Avaiable at: https://content. ces.ncsu.edu/choosing-and-using-edible-flowers-ag-790. Accessed on: April 12th 2021.

MATYJASZCZYK, E.; SMIECHOWSKA, M. Edible flowers. Benefits and risks pertaining to their consumption. Trends in Food Science and Technology, v.91, 670-674, 2019. https://doi.org/10.1016/j.tifs.2019.07.017

MLCEK, J.; ROP, O. Fresh edible flowers of ornamental plants - A new source of nutraceutical foods. Trends in Food Science and Technology, v.22, p.561-569, 2011. https://doi.org/10.1016/j.tifs.2011.04.006

MULÍK, S.; OZUNA, C. Mexican edible flowers: cultural back ground, traditional culinary uses, and potential health benefits. International Journal of Gastronomy and Food Science, v.21, p.100235, 2020. https://doi.org/10.1016/j. ijgfs.2020.100235 
PIRES, T.C.S.P.; BARROS, L.; SANTOS-BUELGA, C.; FERREIRA, I.C.F.R. Edible flowers: emerging components in the diet. Trends in Food Science and Technology, v.93, p. 244-258, 2019. https://doi.org/10.1016/j.tifs.2019.09.020

RIVAS-GARCÍA, L.; NAVARRO-HORTAL. M.D.; ROMERO-MÁRQUEZ, J.M.; FORBESHERNÁNDEZ, T.Y.; VARELA-LÓPEZ, A.; LLOPIS, J.; SÁNCHEZ-GONZÁLEZ, C.; QUILES, J. L. Edible flowers as a health promoter: An evidence-based review. Trends in Food Science and Technology, v.42, 2020. https://doi. org/10.1016/j.tifs.2020.12.007

ROP, O.; MLCEK, J.; JURIKOVA, T.; NEUGEBAUEROVÁ, J.; VABKOVA, J. Edible Flowers - A new promising source of mineral elements in human nutrition. Molecules, v.17, n.12, p.6672-6683, 2012. https://10.3390/molecules 17066672

RODRIGUES, H.; CIELOB, D.P.; GOMÉZ-CORONAC, C.; SILVEIRA, A.A.S.; MARCHESANB, T.A.; GALMARINID, M.V.; RICHARDS, N.S.P.S. Eating flowers? Exploring attitudes and consumers' representation of edible flowers. Food Research International, v.100, p. 227-234, 2017. https://doi.org/10.1016/j. foodres.2017.08.018

TAKAHASHI J.A.; REZENDE F.A.G.G.; MOURA M.A.F.; DOMINGUETE L.C.B.; SANDE D. Edible flowers: Bioactive profile and its potential to be used in food development. Food Research International, v.129, 108868, 2020. https://doi.org/10.1016/j. foodres.2019.108868

YAMAMOTO, Y.; KONO, M. Physiological functions of $70 \%$ ethanol extracts of 6 edible flowers in vitro: A comparative study. Food Nutrition Science, v.9, 314, 2018. https://doi.org/10.4236/ fns.2018.94024
SANTOS, I.C; REIS, S.N.; FACCION, C.E.; CARVALHO, L.M. Flores comestíveis: o que é preciso saber. Belo Horizonte: EPAMIG, Circular Técnica N. 305, $2019 \mathrm{~b}$. Avaiable at: http://www.epamig.br/download/circulartecnica-305/. Accessed on: March 16 ${ }^{\text {th }}, 2021$.

UNIVERSITY OF KENTUCKY. Edible Flowers. Lexington: College of Agriculture, Food and Environment, 2012. $4 p$.

SANTOS, I.C.; SILVA, A.F.; CARVALHO, L.M.; REIS, S.N. Flores comestíveis. In: PAULA JÚNIOR, T.J.; VENZON, M. (ed.). 101 culturas: manual de tecnologias agrícolas, 2ed. Belo Horizonte: EPAMIG, 2019a. p.386401.

NICOLAU, A.I.; GOSTIN, A.I. Safety of Edible Flowers. In: PRAKASH, V.; MARTIN-BELLOSO, O.; KEENER, L.; ASTLEY, S.; BRAUN, S. MCMAHON, H.; LELIEVELD, H. (ed). Safety of Traditional and Ethnic Foods, 2016. p.395-419.

WETZEL, K.; LEE, J.; LEE, C.S.; BINKLEY, M. Comparison of microbial diversity of edible flowers and basil grown with organic versus conventional methods. Canadian Journal of Microbiology, v.56 n.11 p.943-951, 2010. https://doi.org/10.1139/W10-082

ZHENG, J.; YU, X.; MANINDER, M.; XU, B. Total phenolics and antioxidants profiles of commonly consumed edible flowers in China. International Journal of Food Properties, v.21, n.1, p.1524-1540, 2018. https://doi.org/1 $0.1080 / 10942912.2018 .1494195$ 